\title{
Multi-Faceted Role of Silver and Gold Nanoparticles Synthesized from Biowaste and its in vitroAntibacterial, Antifungal and Antidiabetic Activities
}

\author{
R. Latha ${ }^{1, *(D)}$, S.P. Sevarkodiyone ${ }^{2(D)}$, J. Pandiarajan ${ }^{3}$ (D) \\ 1 Department of Zoology, N.M.S.S.Vellaichamy Nadar College (Autonomous), Madurai, Tamil Nadu, India \\ 2 Postgraduate and Research Department of Zoology, AyyaNadar Janaki Ammal College (Autonomous), Sivakasi, Tamil \\ Nadu, India \\ 3 Department of Biotechnology, Ayya Nadar Janaki Ammal College (Autonomous), Sivakasi, Tamil Nadu, India \\ * Correspondence: vasikaranlatha@gmail.com (R.L.);
}

Received: 10.05.2021; Revised: 15.06.2021; Accepted: 18.06.2021; Published: 27.06.2021

\begin{abstract}
Increasing global fish production, increasing the amount of waste generated, unsafe disposal of waste tissues like head, bones, skin, scales, fins etc., into land and open water reservoirs leads to environmental pollution. The role of nanobiotechnology in biowaste management is an innovative strategy to handle environmental issues. This study synthesized silver and gold nanoparticles from prawn heads using one millimolar $\mathrm{AgNO}_{3}$ and $\mathrm{HAuCl}_{4}$. Biosynthesized nanoparticles were characterized by UV -Visible spectroscopy, XRD, FTIR, SEM and EDAX. The maximum absorption spectrum was monitored at $437 \mathrm{~nm}$ for silver and 552 for gold nanoparticles. Antimicrobial activity was assessed using the resazurin assay method. MIC values obtained for the tested organisms revealed antimicrobial activities. P aeruginosa, K. pneumoniae, showed MIC at $15.6 \mu \mathrm{g}$ for silver nanoparticles, and A. niger, A.flavus and C.albicans showed MIC at $125 \mu \mathrm{g}$ for gold nanoparticles synthesized from the prawn head extract. IC 50 values of $\alpha$ - amylase activity were found to be 296 and $356 \mu \mathrm{g} / \mathrm{ml}$ for the silver and gold nanoparticles, respectively. IC S0 $_{5}$ values are about 705 and $2475 \mu \mathrm{g} / \mathrm{ml}$ for the silver and gold nanoparticles, respectively, in $\alpha$-glucosidase activity. Conclusively silver and gold nanoparticles synthesized from prawn head extract (PHE) showed antibacterial, antifungal, and antidiabetic activities.
\end{abstract}

Keywords: prawn head waste; nanoparticles; UV-visible spectroscopy; SEM; XRD; EDAX; FTIR; MIC; antidiabetic activity.

(C) 2021 by the authors. This article is an open-access article distributed under the terms and conditions of the Creative Commons Attribution (CC BY) license (https://creativecommons.org/licenses/by/4.0/).

\section{Introduction}

Biowaste management is a threatening challenge to be taken into concern in view of environmental issues. Environmental effects associated with seafood processing waste discharges include accumulations of waste sludge and whole fish parts in near-shore locations, the generation of toxic hydrogen sulfide gas, increased gathering of scavengers in discharge locations, noxious conditions caused by odors, bacteria and waste decomposition Habitually, seafood waste is burned, landfilled and dumped at sea or left to get spoiled [1]. A large portion of processed fish wastes is underutilized, wasted, or discarded [2]. Dumping of processed wastes leads to deterioration of bioactive rich materials that lead to pollution problems. If unprocessed properly, it will have negative aftermath on human health, biodiversity and the 
environment. It can also cause effluent pollution by this waste and the use of excessive water sources [3-6].

Nanobiotechnology is focused on synthesizing less toxic, renewable materials that are more eco-friendly. Due to the nanotechnological boom, unusual physical, chemical, and biological methods have been developed to synthesize and produce metal nanoparticles [7-12]. The employment of environment-friendly solvents and reagents, reducing high energy consumption methods, using nontoxic biomolecules, such as DNA, proteins, enzymes, carbohydrates, and plant extracts, allows synthesizing biocompatible metallic NPs by reducing metal ions in aqueous solutions [13].

Nanomaterials of metals ( $\mathrm{Au}, \mathrm{Ag}, \mathrm{Se}$, etc.) and their oxides ( $\mathrm{CuO}, \mathrm{ZnO}, \mathrm{NiO}, \mathrm{MnO}$, etc.) have been exploited as antibacterial agents, targeted drug delivery vehicles, antimycotic agents, antioxidant agents, anticancer agents, etc. [14-20]. Among them, Au and Ag NPs are of high significance due to their unique properties. They are extensively employed as antiinflammatory, antibacterial, and antifungal agents in coating catheters, disinfecting medical devices, antimicrobial filters, dental hygiene, eye treatments, and wound dressings $[14,15]$.

Silver nanoparticles are used for their distinct properties, such as good conductivity, chemical stability, catalytic activity, and antimicrobial activity [21]. Their applications include the medical field as well as in water and air purification [22]. The most important role includes treating diseases or targeting cells, such as interacting with the HIV-1 virus and preventing its ability to bind host cells in vitro [23]. Hybrid materials of silver nanoparticles with amphiphilic hyper-branched macromolecules are synthesized for use in surface coatings because of their antibacterial activities [24]. Earlier studies have reported that it holds outstanding anticancer, antiviral and antimicrobial ability with promising biodegradability and less toxicity.

Likewise, gold nanoparticles are proper for some surface immobilization, acting as conducting materials and enhancing the electron transfer between the surface of gold nanoparticles and the target analyte. Gold nanoparticles possess easily tunable and strong optical properties useful in optical imaging. Different kinds of sensors can be constructed based on these special properties of gold nanoparticles such as colorimetric, surface plasmon resonance, electrical, electrochemical, and fluorescent and Bio-Barcode assay sensors [25]. Drug delivery systems depend on nanoparticles, which are used to target malignant brain tumors where conventional therapy is not as effective [26]. It is proved to be the safest and much less toxic agent for drug delivery [27]. The size of the gold nanoparticles shows varied applications like hollow particles are useful in CT imaging cancer therapy [28] and nanoflowers are used as biosensors for disease and removal of dye or heavy metals [29].

Synthesis of metallic nanoparticles using biological samples like phytoextracts, microorganisms like bacteria, fungi, yeast and algae has been studied and reported frequently. Recently, invertebrate species have been experimented on for their ability to synthesize metallic nanoparticles [30]. Especially, marine invertebrates and several crustaceans like lobster, crabs, shrimps etc., are noted for their antimicrobial activities [31, 32]. Pharmacological properties have also been reported in a previous analysis [33, 34]. Nanotechnology's effective delivery of drugs and tissue engineering exhibited vital contributions in translational research related to pharmaceutical products and their applications [35]. The synthesis of nanoparticles mediated through hemolymph of marine crabs has already been reported [36]. Previous studies observed the synthesis of silver and gold nanoparticles from animal tissue like cockroach sp. Periplaneta Americana[37]. 
The development of nanotechnology and the nanoscale size of nanomaterials ranges from about 1-100 $\mathrm{nm}$ established an innovative strategy to drive the bioremediation process forward to the next level of implementation. This application was found to be cost-effective and with the least impact on the ecosystem for treating water pollution [38] and untreated industrial effluents sedimented in soil. However, to evaluate the toxicity of nanoparticles and nanomaterials in soil and water, elucidate their interactions with biotic and abiotic elements, a standard protocol is necessary and needs to be formulated.[39].

In this study, prawn head tissue is used to synthesize silver and gold nanoparticles for the first time. The aims of this study are (i) to synthesis the silver and gold nanoparticles from prawn head tissue; (ii) to analyze the spectroscopic, morphological, chemical and structural characterization of the synthesized nanoparticles; (iii) to evaluate theirs in vitro antibacterial, antifungal and antidiabetic activities.

\section{Materials and Methods}

\subsection{Chemicals and materials required.}

Prawn head waste, silver nitrate $\left(\mathrm{AgNO}_{3} 99.99 \%\right)$, aurochloric acid $\left(\mathrm{HAuCl}_{4}, 99.99 \%\right)$, Whatman filter paper No1, nutrient agar, nutrient broth, potato dextrose agar, potato dextrose broth, 96-well microtiter plate, resazurin tablet $\left(\mathrm{C}_{12} \mathrm{H}_{6} \mathrm{NNaO}_{4}\right), \alpha$-amylase, starch solution ( $1 \%$ w/v), 3,5-dinitrosalicylic acid (DNSA reagent), sodium phosphate buffer, $\alpha$-glucosidase, acarbose, $\mathrm{Na}_{2} \mathrm{CO}_{3}$, $p$-nitrophenyl- $\alpha$-D-glucopyranoside (pNPG).

\subsection{Microorganisms.}

Bacterial species: Pseudomonas aeruginosa, Klebsiella pneumoniae, Salmonella typhi, Staphylococcus aureus and Bacillus subtilis.

Fungal species:Aspergillus niger, Aspergillus flavus, Aspergillus fumigatus, Mucor spp. and Candida albicans.

\subsection{Sample preparation.}

Prawn head waste was collected from the local fish market and shells were removed. Twenty grams of head tissues were ground well using $100 \mathrm{~mL}$ of distilled water. The mixed content was centrifuged at $8000 \mathrm{rpm}$ for $10 \mathrm{~min}$ and the supernatant was filtered using Whatman filter paper No1 and prawn head extract (PHE) was obtained.

\subsection{Biosynthesis of silver and gold nanoparticles from PHE.}

For the synthesis of silver nanoparticles, 20-mL PHE was added to $80 \mathrm{~mL}$ of $1 \mathrm{mM}$ aqueous silver nitrate solution. The mixtures were placed at room temperature, and the bioreduction of silver ions was noted by the change of color of the solution from light yellow to dark brown. The same extract was used to synthesize gold nanoparticles, and 20-mL PHE was added to $80 \mathrm{~mL}$ of $1 \mathrm{mM}$ chloroauric acid and placed in dark conditions under room temperature. Bioreduction of gold chloride is noted by changing the color of the solution from light yellow to dark purple. 


\subsection{Characterization of silver and gold nanoparticles synthesized from PHE.}

Biosynthesized nanoparticles were monitored using a UV-Visible spectrophotometer. The absorption spectrum band was noted within the range of 200-900 nm. Fourier transformed infrared spectroscopy (FTIR) characterization was done to obtain information about functional groups present in nanomaterials using PerkinElmer spectrum version 10.4.4 in the range between $400-4000 \mathrm{~cm}^{-1}$.

$\mathrm{X}$-ray diffraction analysis was conducted to identify and characterize the compounds in the nanoparticles based on the diffraction pattern. From the obtained 2theta value, using Bragg's law, peak indexing and crystallite size were found. SEM provided detailed highresolution images of nanomaterials through a focussed electron beam across the surface and detecting secondary or backscattered electron signals. An Energy Dispersive X-Ray Analyzer (EDX or EDA) analysis was done using Octane Elect EDS system, an enhanced Energy Dispersive Spectroscopy (EDS) platform provided excellent resolution and high throughput at an optimal value with a remarkable low energy sensitivity for light element detection and low voltage $(\mathrm{kV})$ microanalysis of synthesized silver and gold nanoparticles.

\subsection{In vitro antimicrobial activity.}

Antimicrobial activity was determined by the Resazurin Microtitre assay method [40]. This assay is based on converting the blue nonfluorescent dye resazurin, which is converted to pink fluorescent resorufin by mitochondrial and other enzymes such as diaphorase [41]. Resazurin is an indicator that can monitor cell viability and acts as an intermediate electron acceptor[42,43]. Resazurin reduction tests have been used for decades to determine chemical cytotoxicity and minimum inhibitory concentration values for antibiotics [40, 44]. After entering cells, resazurin is reduced to resorufin, which is fluorescent pink. Viable cells continuously convert resazurin to resorufin that changes the color of the culture medium to highly fluorescent pink. The quantity of resorufin produced is related to the number of viable cells.

\subsubsection{Preparation of microbial culture.}

Bacterial pathogens were cultivated in the nutrient broth and subcultured in Muller Hinton broth, whereas the fungal strains were cultivated in the Potato dextrose agar and subcultured in potato dextrose broth sterilely. For the screening of the antibacterial activity, the mid-log phase stage bacterial pathogens were used, whereas for the antifungal screening the spore suspension of freshly prepared fungi was used.

\subsubsection{Preparation of resazurin solution.}

The resazurin tablet $(270 \mathrm{mg}$ ) was dissolved in $40 \mathrm{~mL}$ of sterile distilled water and vortexed to get a homogenous solution.

2.5.3. Screening of minimum inhibitory concentration (MIC) of bacterial and fungal species using resazurin Microtitre Assay.

The test was conducted in 96-well plates under aseptic conditions. A volume of 100$\mu \mathrm{L}$ sample was pipetted out into the first well of the plate. To all other wells, $50 \mu \mathrm{L}$ of nutrient broth was added and serially diluted. To each well $10 \mu \mathrm{l}$ of resazurin indicator solution was 
added. Ten $\mu \mathrm{L}$ of bacterial suspension was added to each well. Each plate was wrapped loosely with plastic wrap to ensure that bacteria did not become dehydrated. The same procedure was performed for antifungal activity and potato dextrose broth was used to culture fungal spores. The plates were maintained at $37^{\circ} \mathrm{C}$ for $18-24 \mathrm{~h}$. The change in the color of the medium was monitored and change in the color from blue to fluorescent pink or colorless was noted as positive. The lowest concentration at which color change occurred was taken as the MIC value [45].

2.6. In vitro antidiabetic activity of silver and gold nanoparticles.

In vitro antidiabetic activity was evaluated using two enzymatic methods, namely (i) $\alpha$ amylase and (ii) $\alpha$-glucosidase inhibitory assays.

2.6.1. Inhibition of $\alpha$-Amylase activity.

$\alpha$ - amylase inhibition was determined to quantify the amount of maltose liberated during the experiment [46]. Different concentrations of silver and gold nanoparticles (100 to $500 \mu \mathrm{g} / \mathrm{mL}$ ) were maintained at room temperature for $30 \mathrm{~min}$ after adding $100 \mu \mathrm{L}$ of $\alpha$-amylase solution $(1 \mathrm{U} / \mathrm{mL})$. A hundred $\mu \mathrm{L}$ of starch solution $(1 \% \mathrm{w} / \mathrm{v})$ was further added to it and the mixture was incubated at room temperature for $10 \mathrm{~min}$. A hundred $\mu \mathrm{L}$ of $96 \mathrm{mM}(3,5-$ dinitrosalicylic acid solution) DNSA was added to stop the reaction and the mixture was heated in a water bath for $5 \mathrm{~min}$. Control was maintained, where the equal quantity of enzyme extract was replaced by sodium phosphate buffer ( $\mathrm{pH}$ 6.9). Absorbance was measured at $540 \mathrm{~nm}$. Acarbose was used as a standard in this assay. The percentage of inhibition was calculated using the formula:

$$
\% \text { of } \alpha \text { - amylase inhibition }=\frac{\text { Abs control }- \text { Abs sample }}{\text { Abs control }} \times 100
$$

where Abs control and Abs sample are the absorbance of the solution without and with sample, respectively.

\subsubsection{Inhibition of $\alpha$ - Glucosidase activity.}

Fifty $\mu \mathrm{L}$ of different concentrations (100 to $500 \mu \mathrm{g} / \mathrm{ml}$ ) of the nanoparticles treated with $10 \mu \mathrm{L}$ of the $\alpha$-glucosidase (maltase) enzyme solution $\left(1 \mathrm{U} / \mathrm{mL}\right.$ ) and maintained at $37^{\circ} \mathrm{C}$ for 20 minutes with an additional $125 \mu \mathrm{L}$ of $0.1 \mathrm{M}$ phosphate buffer (pH 6.8). After 20 minutes, the reaction was started with the addition of $20 \mu \mathrm{L}$ of $1 \mathrm{M}$ pNPG (substrate), and the mixture was incubated for 30 minutes. The reaction was stopped with the addition of $0.1 \mathrm{~N}$ of $\mathrm{Na}_{2} \mathrm{CO}_{3}(50 \mu \mathrm{L})$ and the absorbance was noted at $405 \mathrm{~nm}$. Acarbose was used as a standard for this assay. Enzyme activity was calculated as:

$$
\% \text { of } \alpha \text { - glucosidase inhibition }=\frac{\text { Abs control }- \text { Abs sample }}{\text { Abs control }} \times 100
$$

\section{Results and Discussion}

\subsection{Biosynthesis of silver and gold nanoparticles.}

Bioreduction silver and gold nanoparticles were visualized by the change of colour within $24 \mathrm{~h}$ from light yellow to dark brown and light yellow to purple, respectively (Figures $1(\mathrm{a})-1(\mathrm{~d})$. 
3.2. Characterization of silver and gold nanoparticles.

3.2.1. UV-visible spectroscopy.

UV-Visible spectroscopy is useful to identify the formation of metal nanoparticles in the reaction mixture. The UV-visible absorption spectrum of silver and gold nanoparticles is given in Figures $2(a) \&(b)$. The maximum absorbance monitored with the wavelength ranging between 200 and $900 \mathrm{~nm}$ was peaked at $437 \mathrm{~nm}$ for silver nanoparticles and 552nm for gold nanoparticles. The characteristic surface plasmon band from 500 to $550 \mathrm{~nm}$ indicates the spherical shape of gold nanoparticles [47]. A Similar absorption spectrum was observed in silver nanoparticles onion and marine sponge Acanthella elongate mediated gold nanoparticle synthesis $[48,49]$. This band appears due to the surface plasmon oscillation which is caused by the rise of electrons in resonance with light waves [50]. In metallic nanoparticles, unique color absorption properties can be seen due to the plasmonic absorbance phenomenon. This is particularly useful in understanding surface-modified nanomaterials to increase affinity, reactivity, or compatibility.

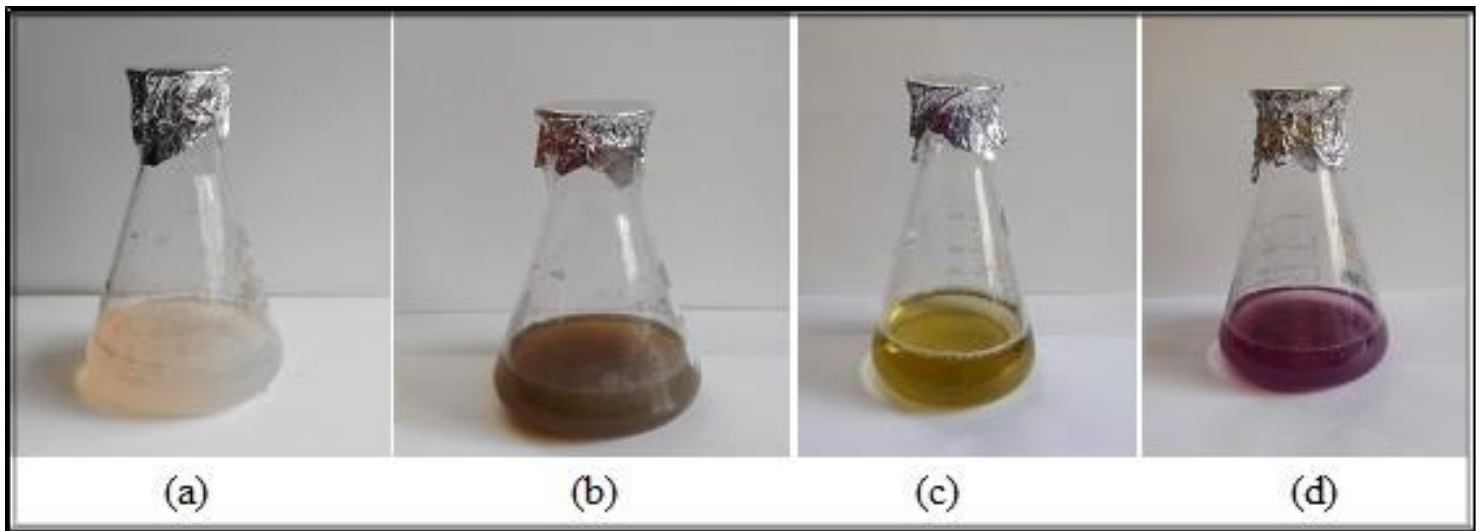

Figure 1. (a) $\mathrm{AgNO}_{3}$ Control; (b) Synthesis of silver nanoparticles; (c) $\mathrm{HAuCl}_{4}$ control; (d) Synthesis of gold nanoparticles.

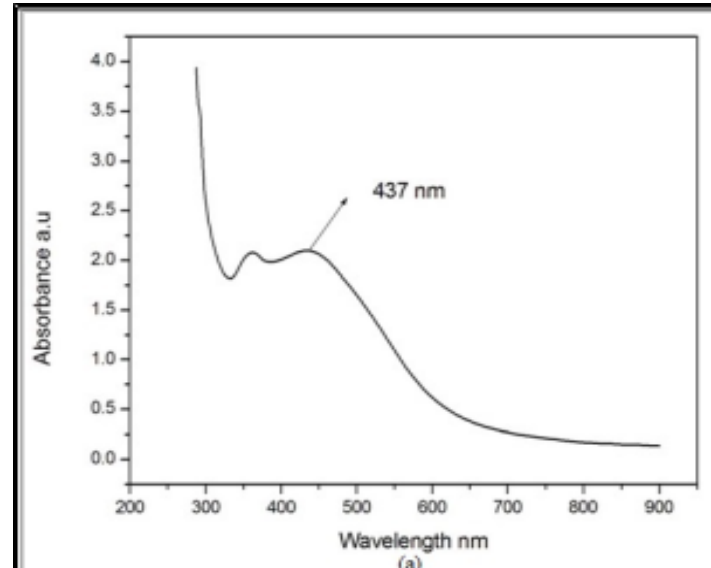

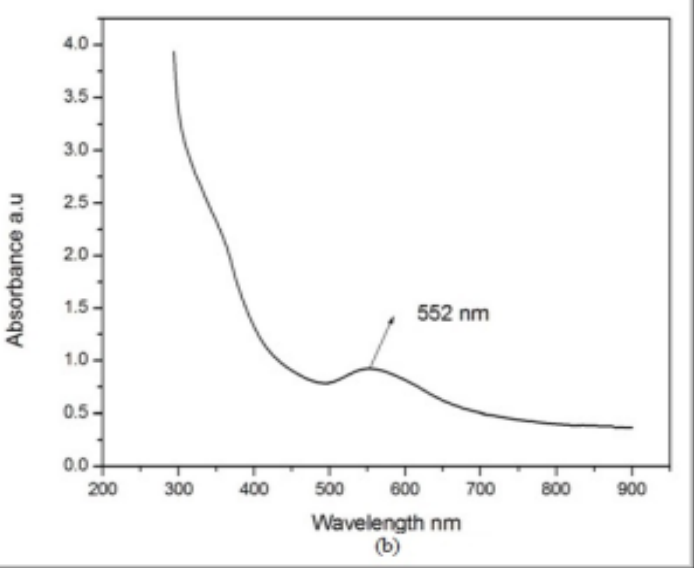

Figure 2. UV- visible spectra of (a) silver; (b) gold nanoparticles.

\subsubsection{Fourier-transform infrared spectroscopy.}

FTIR spectra with the peak value of the infrared region for the synthesized silver and gold nanoparticles are shown in Figures $3 \mathrm{a} \& \mathrm{~b}$. The functional group and the nature of chemical bonds were found using the IR chart from the peak value. Comparative analysis of the functional group and their chemical bonding of the compounds synthesized due to the 
reduction of silver and gold ions (Table:1). The frequency $(\mathrm{cm}-1)$ of characteristic vibration of silver nanoparticles was observed as 3500-3200 (O-H stretch, $\mathrm{H}$ bonded alcohols and phenols), 3000-2850 (C-H stretch, alkanes, 1650-1580 (N-H bond, Primary amines), 1250-1020 (C-N stretch aliphatic amines), and 690-515 (C-Br stretch alkyl halides) [51, 52]. Gold nanoparticles showed characteristic vibration with four peaks of about 3500-3200 (O-H stretch, $\mathrm{H}$ bonded alcohols and phenols), 1650-1580 (N-H bond, Primary amines), 1500-1400(m) C-C stretch (in-ring) aromatics, and 1250-1020 (C-N) stretch aliphatic amines, respectively. Analyzing the FTIR of a nanomaterial, an appropriate surface modification strategy can be decided based on the groups present. It is confirmed that $\mathrm{C}-\mathrm{C}$ stretch aromatics and $\mathrm{C}-\mathrm{Br}$ alkyl halides were not observed in silver nanoparticles, and $\mathrm{C}-\mathrm{H}$ stretch alkanes were not observed in gold nanoparticles. Other functional groups such as alcohols and phenols, alkanes. Primary amines, aliphatic amines and alkyl halides in silver nanoparticles are reported in previous studies [53, 54]. Gold nanoparticles confirmed the presence of alcohols and phenols, primary amines, aromatics, and aliphatic amines. This result demonstrated that the presence of $-\mathrm{OH}$ functional groups derived from polyphenols Oxidized to $\mathrm{C}=\mathrm{O}$ while reducing $\mathrm{Au}$ salts to AuNps. [55].

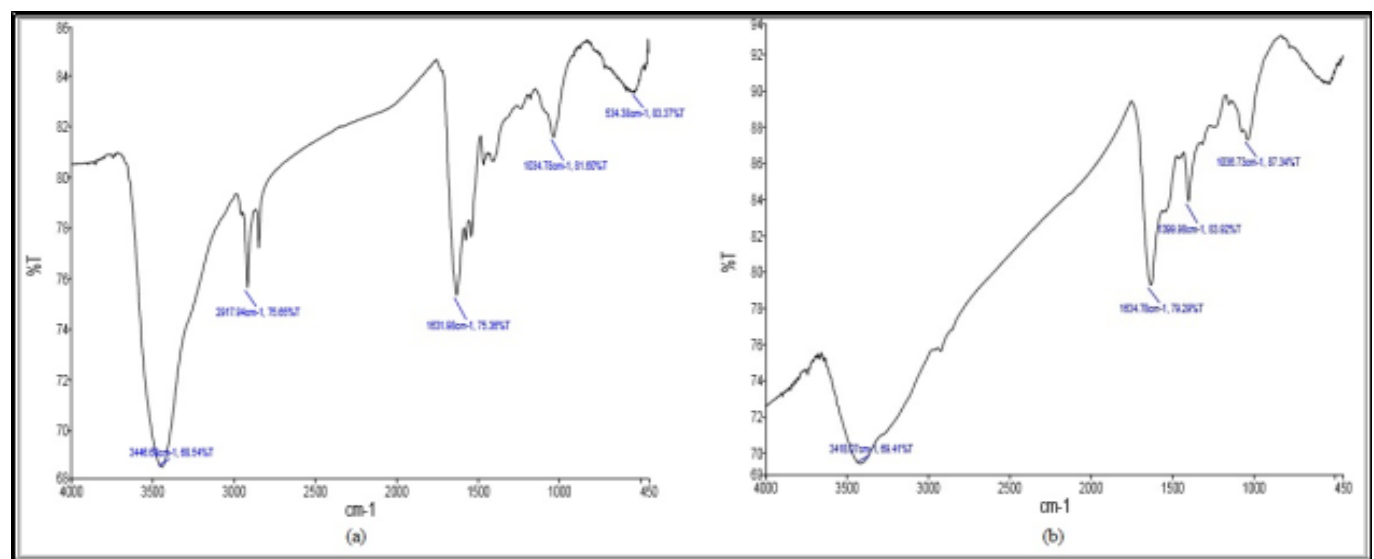

Figure 3. FTIR spectrum of (a) silver; (b) gold nanoparticles.

Table 1. Functional group and chemical bonds of silver and gold nanoparticles.

\begin{tabular}{c|c|c|c|c}
$\begin{array}{c}\text { Frequency } \\
\mathbf{c m}^{-1}\end{array}$ & Chemical bond & Chemical components & $\begin{array}{c}\text { Peak observed } \\
\text { Silver nanoparticles }\end{array}$ & $\begin{array}{c}\text { Peak Observed } \\
\text { Gold nanoparticles }\end{array}$ \\
\hline $3500-3200$ & O-H stretch & Alcohols and phenols & 3446.68 & 3418.07 \\
\hline $3000-2850$ & C-H stretch & Alkanes & 2917.94 & - \\
\hline $1650-1580$ & N-H bend & Primary Amines & 1631.98 & 1634.78 \\
\hline $1400-1500$ & C-C stretch & Aromatics & - & 1399.98 \\
\hline $1250-1020$ & C-N stretch & Aliphatic amines & 1034.78 & 1046.73 \\
\hline $690-400$ & C-Br stretch & Alkyl halides & - & 534.38
\end{tabular}

\subsubsection{SEM and EDAX analysis.}

Scanning electron microscopy (SEM) analyses of silver and gold nanoparticles are given in Figures $4(a) \&(b)$, respectively. SEM images of the silver nanoparticles showed a spherical shape and size ranging from about $23 \mathrm{~nm}$ to $28 \mathrm{~nm}$. Similarly, the synthesized gold nanoparticles showed a spherical shape, and their size ranged from about $20 \mathrm{~nm}$ to $27 \mathrm{~nm}$. The average sizes of silver and gold nanoparticles were noted as $26 \mathrm{~nm}$ and $24 \mathrm{~nm}$, respectively.

Energy-dispersive X-ray analysis (EDAX) spectra of the nanoparticles are given in Figures 5(a)\&(b). EDAX spectra revealed a peak for elemental silver at $3 \mathrm{kev}$ and the presence of a strong peak of gold at $2 \mathrm{kev}$. The elemental compositions of silver and gold nanoparticles were found to be 33.3 and $54.87 \%$, respectively. The high-resolution, three-dimensional 
images of nanomaterials produced by scanning electron microscopy provided topographical, morphological, and compositional information. The average size of the silver and gold nanoparticles was found to be $26 \mathrm{~nm}$ and $24 \mathrm{~nm}$, respectively. Similar work revealed that dried fruit extract of $T$. terrestris is reported to be used as a capping agent in silver nanoparticle synthesis with a size range from 16 to $28 \mathrm{~nm}$ [56]. Gold nanoparticle synthesis using Artocarpus heterophyllus fruit extract exhibited an aspherical size of about 20-25 $\mathrm{nm}$ [52]. EDAX profile confirmed the synthesis of silver and gold nanoparticles from PHE.
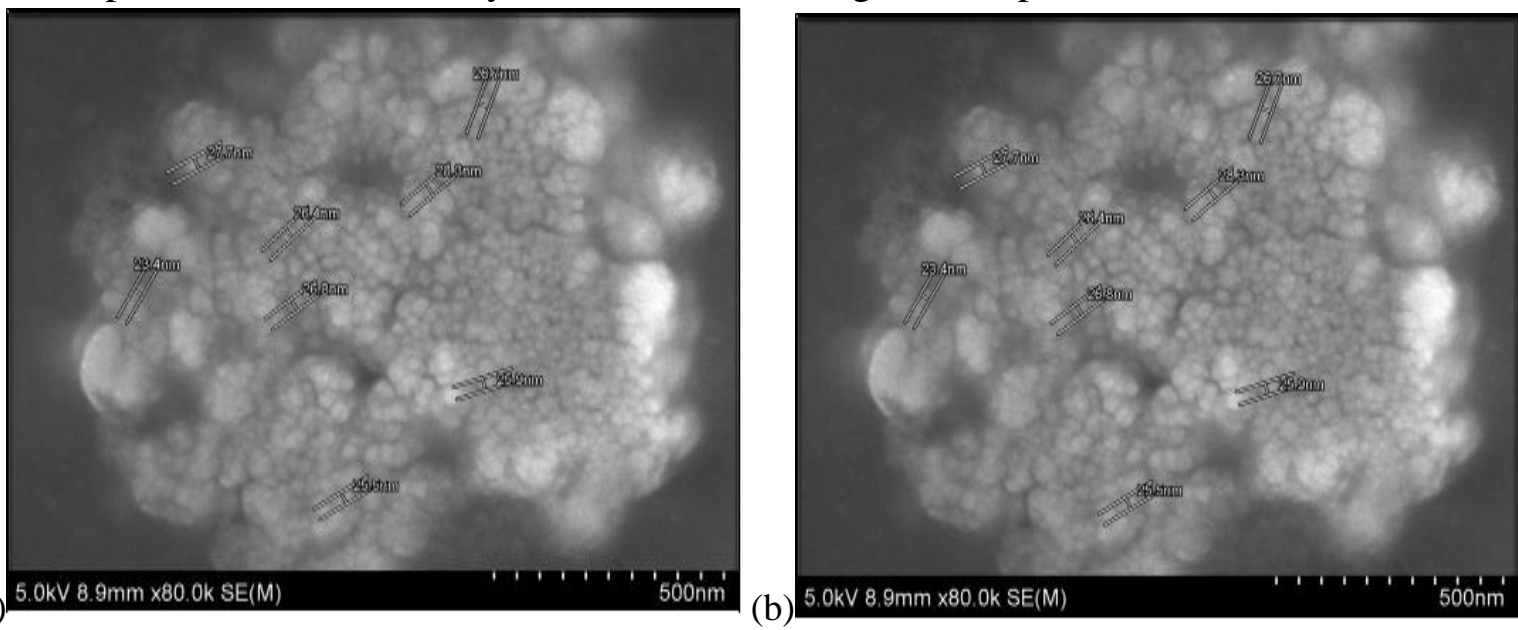

Figure 4. SEM image of (a) Silver nanoparticles:(b) gold nanoparticles.

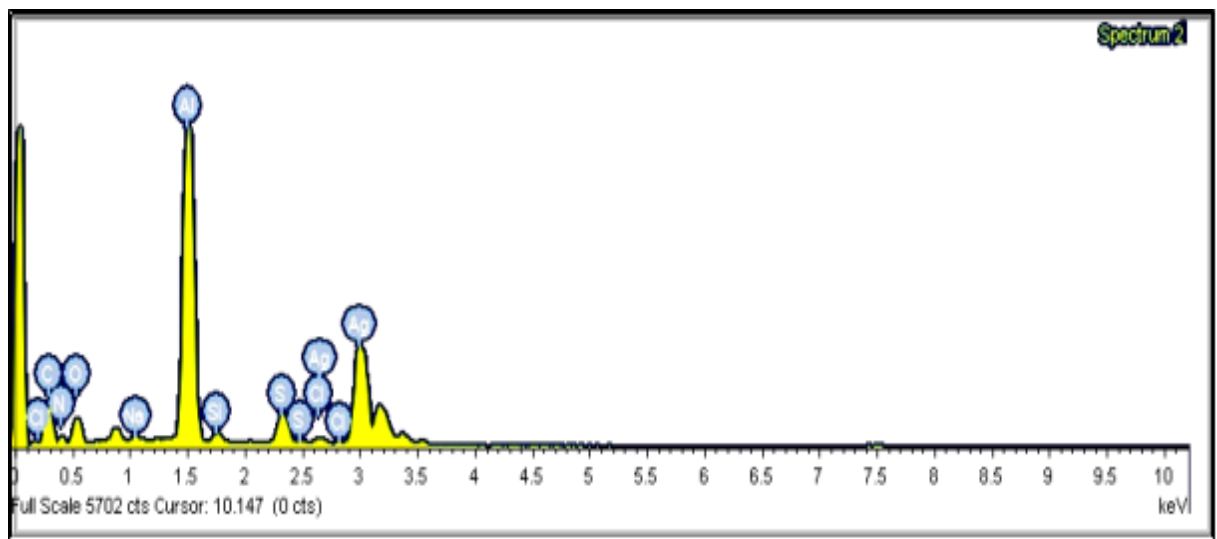

(a)

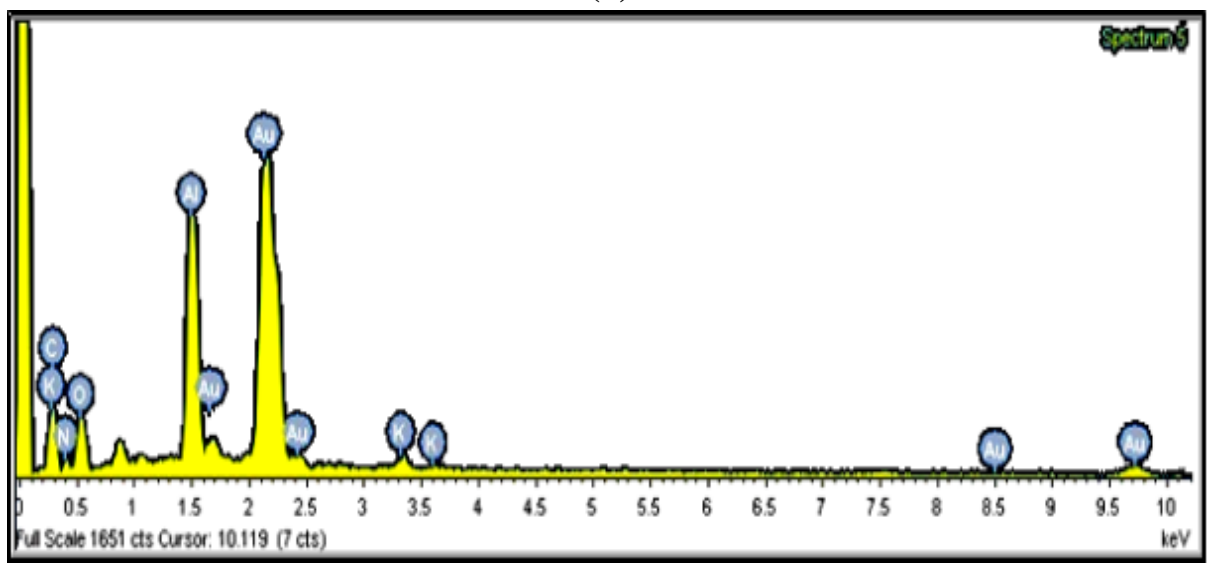

(b)

Figure 5. EDAX spectral view of (a) silver nanoparticles: (b) gold Nanoparticles. 


\subsubsection{X-ray diffraction pattern.}

X-ray diffraction (XRD) pattern revealed the crystalline structure of the biosynthesized silver and gold nanoparticles. The diffraction peak is plotted as the 2theta value of Bragg's law against intensity counts (Figures 6 (a) \&(b)). The silver nanoparticles exhibited six prominent peaks at the 2 theta value of about $32.80^{\circ}, 36.69^{\circ}, 42.87^{\circ}, 63.26^{\circ}, 67.64^{\circ}$, and $76.41^{\circ}$, which corresponds to the Miller indices $\{100,100,110,111,200$ and 210$\}$. In contrast, synthesized gold nanoparticles exhibited five prominent peaks at the 2theta value of about $32.80^{\circ}, 36.68^{\circ}$, $42.87^{\circ}, 63.25^{\circ}$, and $76.34^{\circ}$ which corresponds to Miller indices $\{100,100,110,200$, and 210$\}$. XRD analysis showed that the most intense signal of crystalline silver nanoparticles displayed the preferential orientation of the crystals toward the (111) plane [57]. Comparative peak list showing 2theta value, d spacing FWHM, lattice plane, the crystallite size of the silver and gold nanoparticles is presented in Table: 2. Diffraction outputs of a graph showing the intensity of diffracted X-rays respective to the angle of incidence of the X-ray beam with the sample. The diffraction pattern is useful in determining atomic distances between different atomic layers in the crystal. It also serves as a fingerprint for a material. The diffraction pattern is due to the scattering of $\mathrm{x}$-rays which revealed the atomic arrangement within the crystal. It computes the molecular form factor by accounting for the scattering factors of the atoms in the molecule and their relative positions [58]. The presence of multiple peaks confirmed the multiple faceted growth orientation of silver and gold nanoparticles synthesized from PHE. A similar pattern of $\mathrm{XRD}$ is noted in Lysiloma acapulcensis silver-mediated nanoparticle synthesis [59].

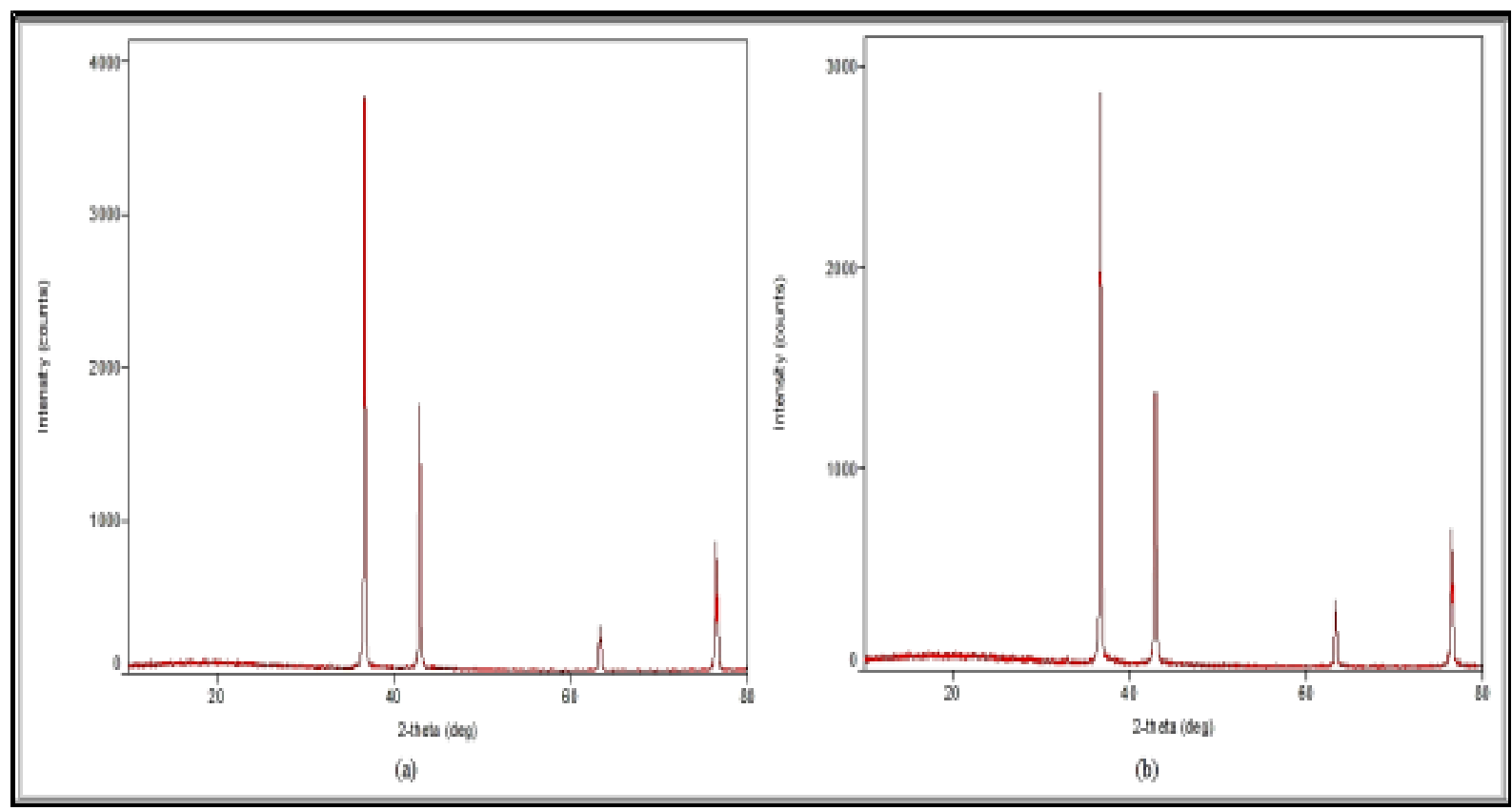

Figure 6. XRD pattern of (a) silver (b) gold nanoparticles.

Table 2. Peak list analysis of XRD patterns of nanoparticles.

\begin{tabular}{c|c|c|c|c|c|c|c} 
Nanoparticles & $\mathbf{2}^{\boldsymbol{\theta}}$ & $\mathbf{d}(\mathbf{A n g})$ & $\mathbf{F W H M}(\mathbf{d e g})$ & $\mathbf{h}$ & $\mathbf{K}$ & $\mathbf{l}$ & The crystallite size (nm) \\
\hline \multirow{4}{*}{ Silver } & 32.8 & 2.73 & $0.09(3)$ & 1 & 0 & 0 & 96.14 \\
\cline { 2 - 7 } & 36.69 & 2.45 & $0.14(2)$ & 1 & 0 & 0 & 84.09 \\
\cline { 2 - 8 } & 42.88 & 2.11 & $0.15(4)$ & 1 & 1 & 0 & 60.26 \\
\cline { 2 - 8 } & 63.26 & 1.47 & $0.18(6)$ & 1 & 1 & 1 & 55.09 \\
\cline { 2 - 8 } & 67.64 & 1.38 & $0.11(6)$ & 2 & 0 & 0 & 90.84 \\
\cline { 2 - 7 } & 76.41 & 1.25 & $0.15(4)$ & 2 & 1 & 0 & 69.05 \\
\hline \multirow{5}{*}{ Gold } & 32.80 & 2.73 & $0.12(4)$ & 1 & 0 & 0 & 66.56 \\
\cline { 2 - 7 } & 36.68 & 2.45 & $0.15(3)$ & 1 & 0 & 0 & 43.29
\end{tabular}




\begin{tabular}{c|c|c|c|c|c|c|c}
\hline \multirow{2}{*}{ Nanoparticles } & $\mathbf{2}^{\boldsymbol{\theta}}$ & $\mathbf{d}($ Ang) & FWHM (deg) & $\mathbf{h}$ & $\mathbf{K}$ & $\mathbf{l}$ & The crystallite size (nm) \\
\hline \multirow{5}{*}{} & 42.87 & 2.11 & $0.18(4)$ & 1 & 1 & 0 & 37.00 \\
\cline { 2 - 8 } & 63.25 & 1.47 & $0.17(8)$ & 2 & 0 & 0 & 40.96 \\
\cline { 2 - 8 } & 76.38 & 1.25 & $0.18(5)$ & 2 & 1 & 0 & 41.26
\end{tabular}

\subsection{In vitro antimicrobial activity.}

3.3.1. In vitro antibacterial activity of silver and gold nanoparticles.

The most promising approach for abating or avoiding microbial drug resistance is the use of nanoparticles. Due to various mechanisms, metallic nanoparticles can preclude or overwhelm the multidrug resistance [60].

Table 3. MIC value of silver and gold nanoparticles against bacterial species.

\begin{tabular}{|c|c|c|c|c|c|c|c|c|c|c|c|c|}
\hline \multirow[b]{2}{*}{ S.No } & \multirow[b]{2}{*}{$\begin{array}{c}\text { Bacterial } \\
\text { species/sample }\end{array}$} & \multicolumn{10}{|c|}{ Growth of inhibition at various concentrations $(\mu \mathrm{g})$} & \multirow[b]{2}{*}{$\begin{array}{c}\text { Negative } \\
\text { control }\end{array}$} \\
\hline & & 1000 & 500 & 250 & 125 & 62.5 & 31.2 & 15.6 & 7.8 & STD & DMSO & \\
\hline \multicolumn{13}{|c|}{ Silver nanoparticles } \\
\hline 1 & P. aeruginosa & - & - & - & - & - & - & - & + & - & + & + \\
\hline 2 & K. pneumonia & - & - & - & - & - & - & - & + & - & + & + \\
\hline 3 & S. typhi & - & - & - & - & - & - & + & + & - & + & + \\
\hline 4 & S. aureus & - & - & - & - & - & - & + & + & - & + & + \\
\hline 5 & B. subtilis & - & - & - & - & - & - & + & + & - & + & + \\
\hline \multicolumn{13}{|c|}{ Gold nanoparticles } \\
\hline 1 & P.aeruginosa & - & - & - & - & + & + & + & + & - & + & + \\
\hline 2 & K.pneumoniae & - & - & - & - & + & + & + & + & - & + & + \\
\hline 3 & S.typhi & - & - & - & + & + & + & + & + & - & + & + \\
\hline 4 & S.aureus & - & - & - & - & + & + & + & + & - & + & + \\
\hline 5 & B.subtilis & - & - & - & - & - & + & + & + & - & + & + \\
\hline
\end{tabular}

Std-streptomycin (Positive control), DMSO-Vehicle control, +ve - growth; -ve - No growth

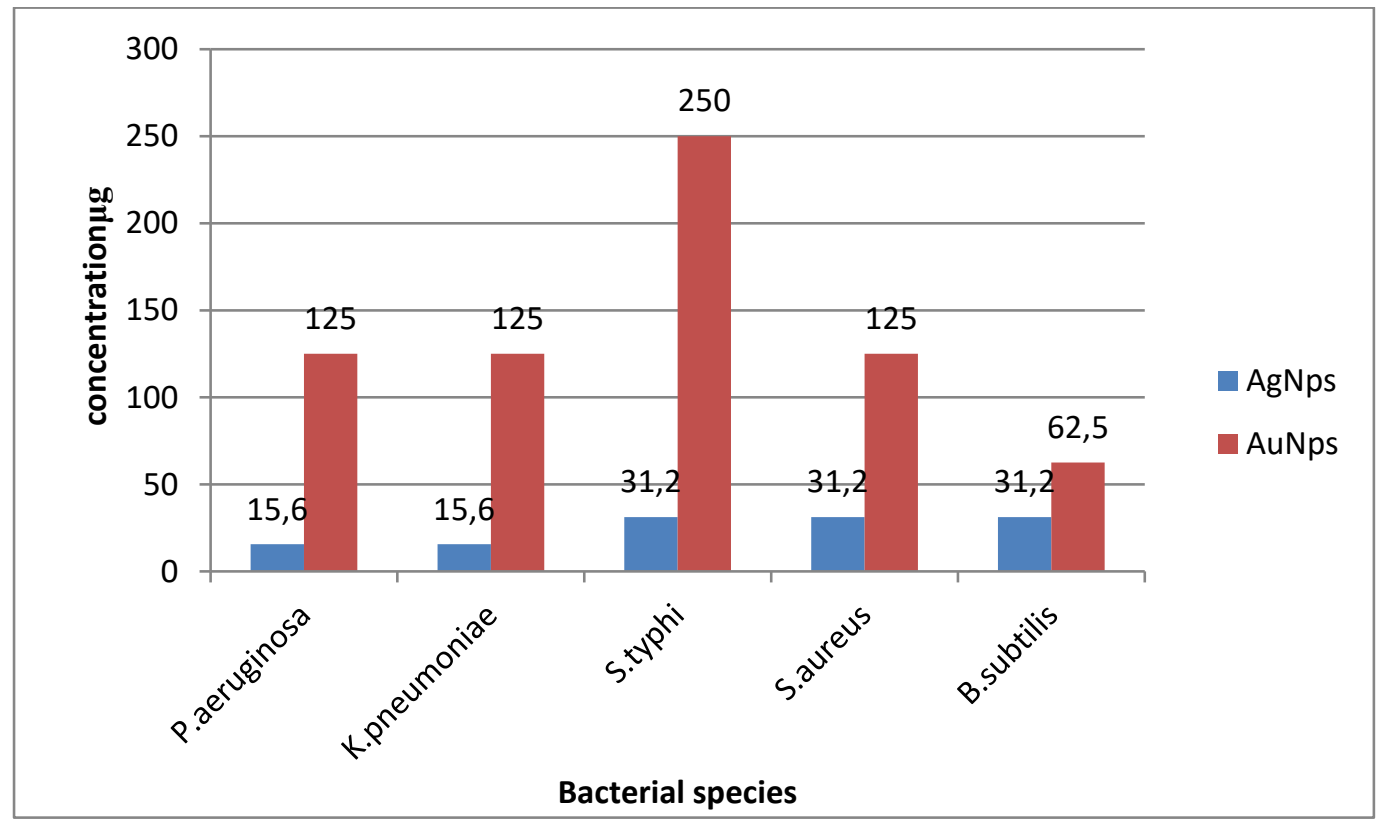

Figure 7. In vitro antibacterial activity of silver and gold nanoparticles. 
The MIC values of the silver and gold nanoparticles tested against bacterial species are shown in Table 3. Among the bacterial species, P. aeruginosa and K. pneumoniae, showed MIC at $15.6 \mu \mathrm{g}$ for silver nanoparticles, which were similar to procyanidin capped silver nanoparticles [61] and $125 \mu \mathrm{g}$ for gold nanoparticles, whereas S. typhi, S. aureus, and B. subtilis exhibited MIC at $31.2 \mu \mathrm{g}$ for silver and 250, $125 \& 62.5 \mu \mathrm{g}$ for gold nanoparticles (Figure:7). Earlier studies reported antibacterial activities of polychaete extracts in the disc diffusion method [62].

3.3.2. In vitro antifungal activity of silver and gold nanoparticles.

The MIC values of the silver and gold nanoparticles tested against fungal species are shown in Table 4.

Table 4. MIC value of silver and gold nanoparticles against fungal species.

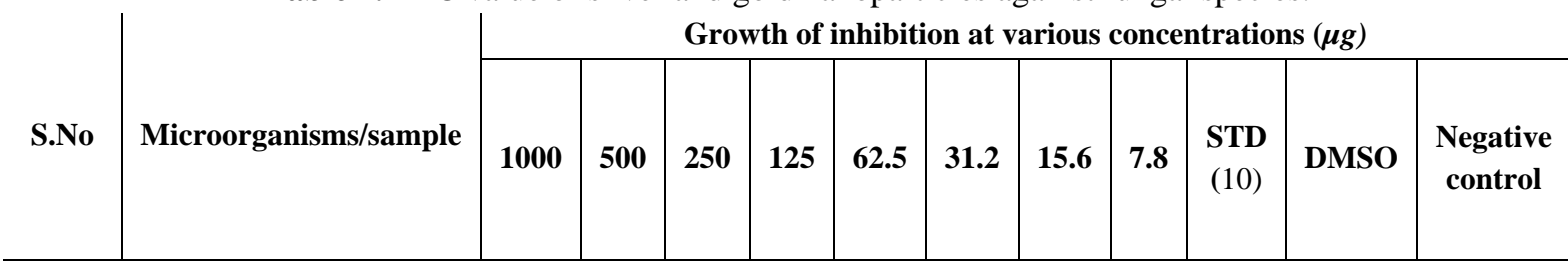

Silver nanoparticles

\begin{tabular}{l|c|c|c|c|c|c|c|c|c|c|c|c}
\hline 1 & A. niger & - & - & - & + & + & + & + & + & - & + & + \\
\hline 2 & A.flavus & - & - & - & + & + & + & + & + & - & + & + \\
\hline 3 & A.fumigates & - & - & + & + & + & + & + & + & - & + & + \\
\hline 4 & Mucor spp & - & - & - & + & + & + & + & + & - & + & + \\
\hline 5 & C. albicans & - & + & + & + & + & + & + & + & - & + & + \\
\hline \\
\hline 1
\end{tabular}

Std-streptomycin (Positive control), DMSO-Vehicle control, +ve - growth; -ve - No growth

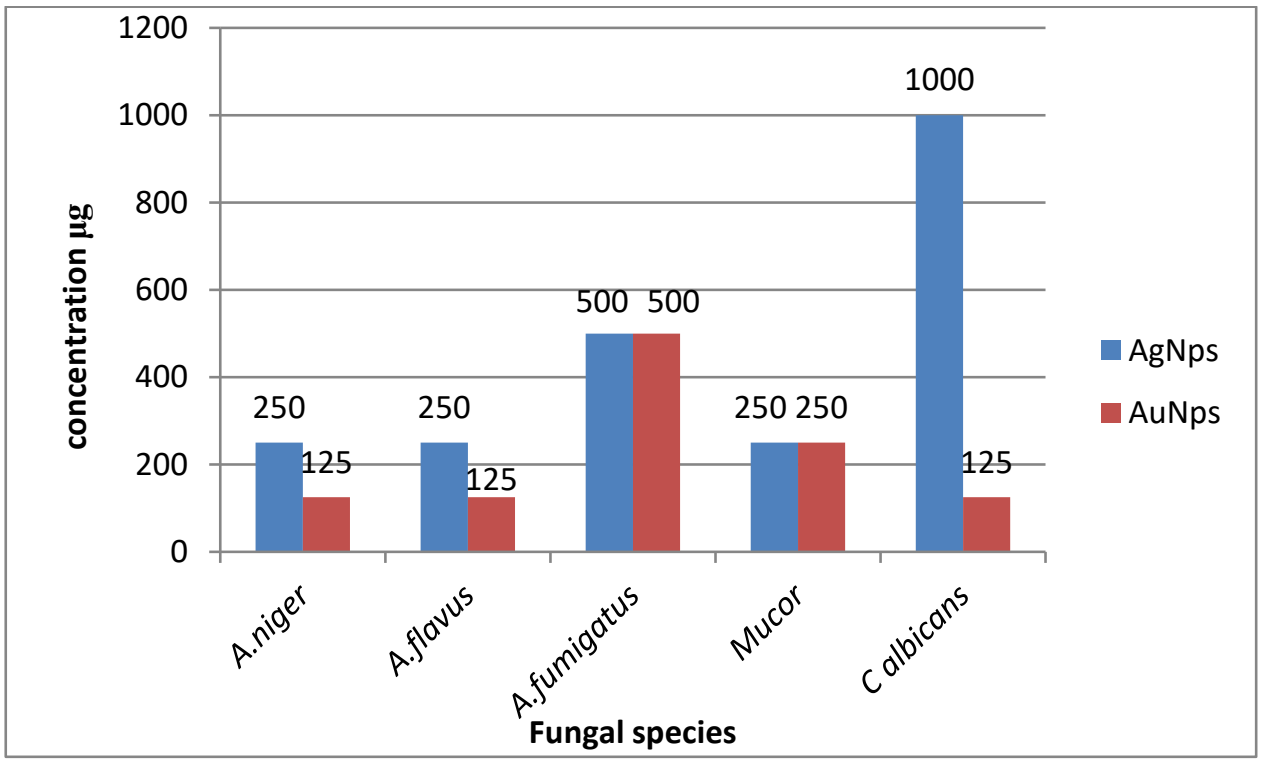

Figure 8. In vitro antifungal activitity of silver and gold nanoparticles. 
Among the fungal species, A. niger, A. flavus, and Mucor spp. showed MIC at $250 \mu \mathrm{g}$, whereas A. fumigatus and C.albicans showed 500 and $1000 \mu \mathrm{g}$ for silver nanoparticles, respectively. In gold nanoparticles A. niger, A. flavus, and C. albicans showed MIC at $125 \mu \mathrm{g}$, whereas A. fumigatus and Mucor spp. exhibited MIC at 500 and $250 \mu \mathrm{g}$, respectively (Figure: 8). An earlier study reported a similar effect against fungal species by silver nanoparticles [63].

\subsection{In vitro antidiabetic activity of silver and gold nanoparticles.}

\subsubsection{Inhibition assay of $\alpha$ - amylase and $\alpha$-glucosidase.}

$\alpha$ - amylase found in pancreatic juice and saliva breaks down complex molecules into simple molecules. Alternatively, mammalian mucosal $\alpha$-glucosidase of the small intestine catalyzes the digestion of starch and disaccharides [64].

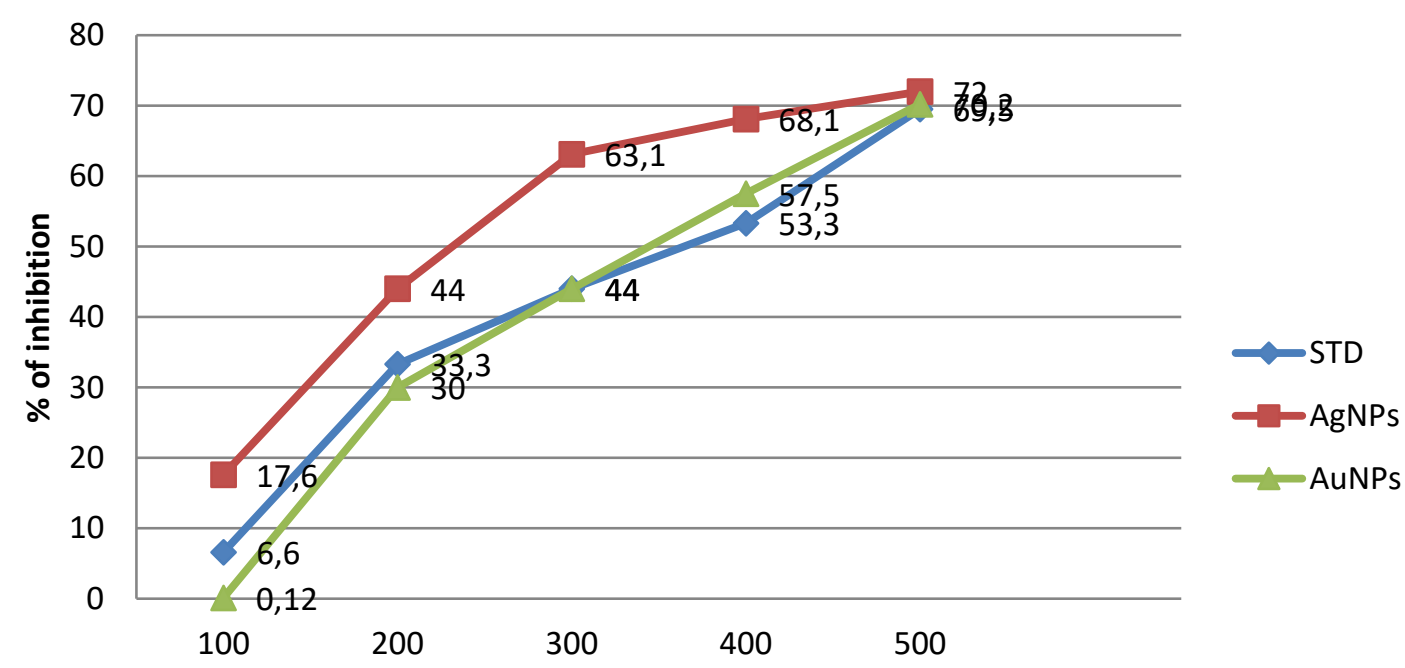

concentration $\mu \mathrm{g}$

Figure 9. $\alpha$-amylase activity of silver and gold nanoparticles.

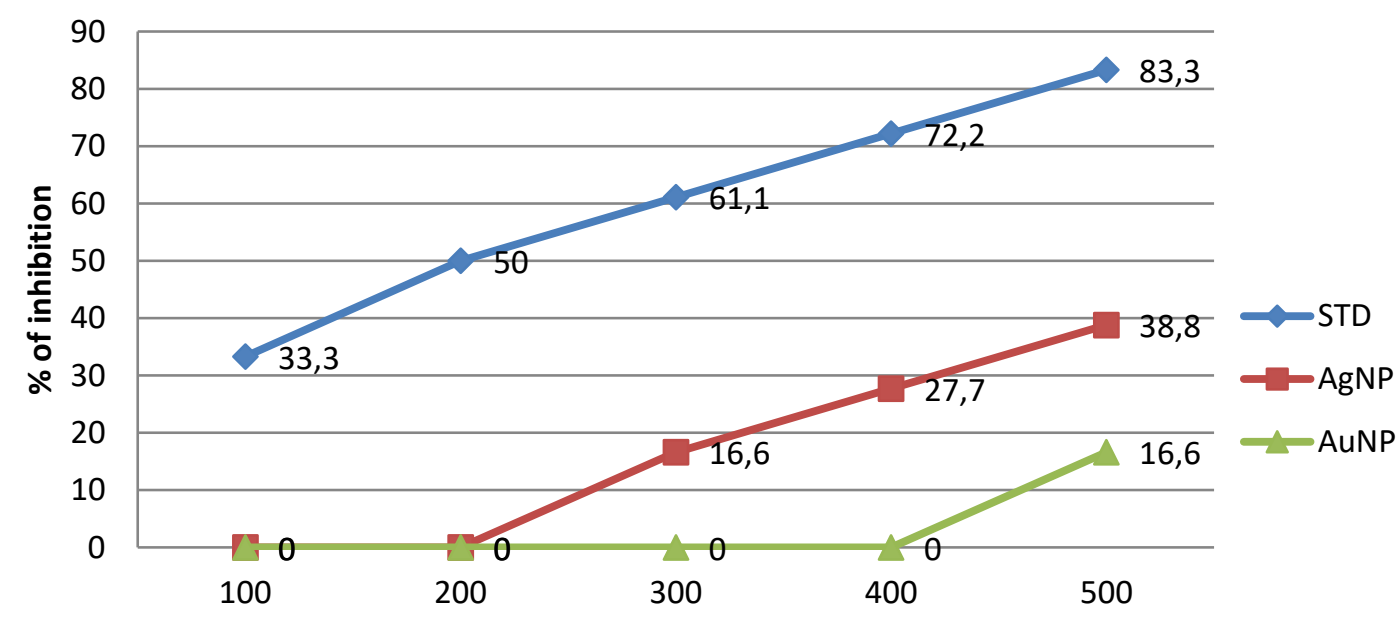

Concentration $\mu \mathrm{g}$

Figure 10. The $\alpha$-glucosidase activity of silver and gold nanoparticles.

Inhibition of -amylase and glucosidase delays carbohydrates' metabolism and diminishes the postprandial blood glucose excursion [65]. $\alpha$-amylase and $\alpha$-glucosidase 
inhibitors play effective role in controlling hyperglycemia after consuming meals [66]. Many medicinal plants provide natural inhibitors of $\alpha$-amylase and $\alpha$-glucosidase that have been found to be effective than chemotherapeutic drugs [67]. The silver and gold nanoparticles dose-dependently showed inhibitory effects on enzymes (Figures: $9 \& 10$ ). IC 50 values of $\alpha$ amylase activity was found to be 296 and $356 \mu \mathrm{g} / \mathrm{ml}$ for the silver and gold nanoparticles, respectively, and for $\alpha$-glucosidase, the IC 50 values of about 705 and $2475 \mu \mathrm{g} / \mathrm{ml}$ for the silver and gold nanoparticles, respectively [68]. The inhibitory potential of AgNPs for the amylase activity shall have a prominent role in controlling hyperglycemia and, therefore may be useful in managing diabetes [69]. Comparatively synthesized nanoparticles showed minimal $\mathrm{IC}_{50}$ values in $\alpha$ - amylase assay than $\alpha$-glucosidase assay.

\section{Conclusions}

Every biological system has unique potentialities to supply metallic nanoparticles. However, not all biological organisms can produce nanoparticles because their enzymatic activities and intrinsic metabolic processes vary with each organism. Therefore, biological organisms, their extracts, secretions, excretions, and processed waste are used to synthesize metallic nanoparticles through bio-reduction of metallic particles leading to the synthesis of nanoparticles. These biosynthesized metallic nanoparticles have a range of unlimited pharmaceutical applications, including the delivery of drugs or genes, detection of pathogens or proteins, and tissue engineering. This study attempt was to utilize extract from prawn head waste to synthesize silver and gold nanoparticles. Prawn head is being considered waste in rural, semi-urban and urban areas and leads to unsafe environmental disposal. Spectroscopic, morphological, and structural characterization confirmed the synthesis of metallic nanoparticles using prawn head extract. Antibacterial and antifungal activities revealed the MIC of various species tested. The antidiabetic assay showed its percentage inhibition in $\alpha-$ amylase and $\alpha$-glucosidase to a promising extent, and the $\mathrm{IC}_{50}$ value was calculated.

\section{Funding}

This research received no external funding.

\section{Acknowledgments}

The Authors thank the Management and Principal, Ayya Nadar Janaki Ammal College (Autonomous), Sivakasi, for providing facilities to carry out this research work. We acknowledge the support and necessary provision granted by N.M.S.S.Vellaichamy Nadar College (Autonomous), Nagamalai, Madurai. We thank Dr.R.Murugan, Assistant professor of Botany, Ayya Nadar Janaki Ammal College (Autonomous), Sivakasi for his support.

\section{Conflicts of Interest}

The authors declare no conflict of interest.

\section{References}

1. Xu, Y.; Bajaj, M.; Schneider, R.; Grage, S.L.; Ulrich, A.S.; Winter, J.; Gallert, C. Transformation of the matrix structure of shrimp shells during bacterial deproteination and demineralization. Microbial Cell Factories 2013, 12, 90, https://doi.org/10.1186/1475-2859-12-90. 
2. Sachindra, M.M.; Mahendrakar, M.S. Fish processing by-products: quality assessment and applications. Studium Press, Houston, 2014, 413.

3. Nogueira, L.F.B.; Guidelli, É.J.; Jafari, S.M.; Ramos, A.P. 7 - Green synthesis of metal nanoparticles by plant extracts and biopolymers. In Handbook of Food Nanotechnology, Jafari, S.M., Ed. Academic Press: 2020; https://doi.org/10.1016/B978-0-12-815866-1.00007-8.

4. Hekmati, M.; Hasanirad, S.; Khaledi, A.; Esmaeili, D. Green synthesis of silver nanoparticles using extracts of Allium rotundum 1, Falcaria vulgaris Bernh, and Ferulago angulate Boiss, and their antimicrobial effects in vitro. Gene Reports 2020, 19, 100589, https://doi.org/10.1016/j.genrep.2020.100589.

5. Khalaj, M.; Kamali, M.; Costa, M.E.V.; Capela, I. Green synthesis of nanomaterials - A scientometric assessment. Journal of Cleaner Production $2020, \quad 267, \quad$ 122036, https://doi.org/10.1016/j.jclepro.2020.122036.

6. Yadi, M.; Mostafavi, E.; Saleh, B.; Davaran, S.; Aliyeva, I.; Khalilov, R.; Nikzamir, M.; Nikzamir, N.; Akbarzadeh, A.; Panahi, Y.; Milani, M. Current developments in green synthesis of metallic nanoparticles using plant extracts: a review. Artificial Cells, Nanomedicine, and Biotechnology 2018, 46, S336-S343, https://doi.org/10.1080/21691401.2018.1492931.

7. Sherin, L.; Sohail, A.; Amjad, U.-e.-S.; Mustafa, M.; Jabeen, R.; Ul-Hamid, A. Facile green synthesis of silver nanoparticles using Terminalia bellerica kernel extract for catalytic reduction of anthropogenic water pollutants. Colloid and Interface Science Communications 2020,37 , 100276,https://doi.org/10.1016/j.colcom.2020.100276.

8. Li, M.; Yu, H.; Cheng, Y.; Guo, Y.; Yao, W.; Xie, Y. Simultaneous and rapid determination of polycyclic aromatic hydrocarbons by facile and green synthesis of silver nanoparticles as effective SERS substrate. Ecotoxicol. Environ. Saf. 2020, 200, 110780, https://doi.org/10.1016/j.ecoenv.2020.110780.

9. Trotsiuk, L.; Antanovich, A.; Lizunova, A.; Kulakovich, O. Direct synthesis of amphiphilic polyvinylpyrrolidone-capped gold nanoparticles in chloroform. Colloid and Interface Science Communications 2020, 37, 100289, https://doi.org/10.1016/j.colcom.2020.100289.

10. Adamo, C.B.; Junger, A.S.; Bressan, L.P.; da Silva, J.A.F.; Poppi, R.J.; de Jesus, D.P. Fast and straightforward in-situ synthesis of gold nanoparticles on a thread-based microfluidic device for application in surface-enhanced Raman scattering detection. Microchem. J. 2020, 156, 104985, https://doi.org/10.1016/j.microc.2020.104985.

11. Bandeira, M.; Giovanela, M.; Roesch-Ely, M.; Devine, D.M.; da Silva Crespo, J. Green synthesis of zinc oxide nanoparticles: A review of the synthesis methodology and mechanism of formation. Sustainable Chemistry and Pharmacy 2020, 15, 100223,https://doi.org/10.1016/j.scp.2020.100223.

12. Ohara, Y.; Akazawa, K.; Shibata, K.; Hirota, T.; Kodama, Y.; Amemiya, T.; Wang, J.; Yamaguchi, T. Seedmediated gold nanoparticle synthesis via photochemical reaction of benzoquinone. Colloids Surf. Physicochem. Eng. Aspects 2020, 586, 124209, https://doi.org/10.1016/j.colsurfa.2019.124209.

13. Hou, D.; O'Connor, D. Chapter 1 - Green and sustainable remediation: concepts, principles, and pertaining research. In Sustainable Remediation of Contaminated Soil and Groundwater, Hou, D., Ed. ButterworthHeinemann: 2020; https://doi.org/10.1016/B978-0-12-817982-6.00001-X.

14. Boomi, P.; Ganesan, R.M.; Poorani, G.; Gurumallesh Prabu, H.; Ravikumar, S.; Jeyakanthan, J. Biological synergy of greener gold nanoparticles by using Coleus aromaticus leaf extract. Materials Science and Engineering: C 2019, 99, 202-210, https://doi.org/10.1016/j.msec.2019.01.105.

15. Parthiban, E.; Manivannan, N.; Ramanibai, R.; Mathivanan, N. Green synthesis of silver-nanoparticles from Annona reticulata leaves aqueous extract and its mosquito larvicidal and antimicrobial activity on human pathogens. Biotechnology Reports 2019, 21, e00297, https://doi.org/10.1016/j.btre.2018.e00297.

16. Lian, S.; Diko, C.S.; Yan, Y.; Li, Z.; Zhang, H.; Ma, Q.; Qu, Y. Characterization of biogenic selenium nanoparticles derived from cell-free extracts of a novel yeast Magnusiomyces ingens. 3 Biotech 2019, 9, 221, https://doi.org/10.1007/s13205-019-1748-y.

17. Ijaz, F.; Shahid, S.; Khan, S.A.; Ahmad, W.; Zaman, S. Green synthesis of copper oxide nanoparticles using Abutilon indicum leaf extract: Antimicrobial, antioxidant and photocatalytic dye degradation activitie. Tropical Journal of Pharmaceutical Research 2017, 16, 743-753,https://doi.org/10.4314/tjpr.v16i4.2.

18. Khan, S.A.; Noreen, F.; Kanwal, S.; Iqbal, A.; Hussain, G. Green synthesis of $\mathrm{ZnO}$ and Cu-doped $\mathrm{ZnO}$ nanoparticles from leaf extracts of Abutilon indicum, Clerodendrum infortunatum, Clerodendrum inerme and investigation of their biological and photocatalytic activities. Mater Sci Eng C Mater Biol Appl 2018, 82, 4659, https://doi.org/10.1016/j.msec.2017.08.071. 
19. Abbasi, B.A.; Iqbal, J.; Mahmood, T.; Ahmad, R.; Kanwal, S.; Afridi, S. Plant-mediated synthesis of nickel oxide nanoparticles $(\mathrm{NiO})$ via Geranium wallichianum: characterization and different biological applications. Materials Research Express 2019, 6, 0850a0857,https://doi.org/10.1088/2053-1591/ab23e1.

20. Khan, S.A.; Noreen, F.; Kanwal, S.; Iqbal, A.; Hussain, G. Green synthesis of ZnO and Cu-doped ZnO nanoparticles from leaf extracts of Abutilon indicum, Clerodendrum infortunatum, Clerodendrum inerme and investigation of their biological and photocatalytic activities. Materials Science and Engineering: C 2018, 82, 46-59, https://doi.org/10.1016/j.msec.2017.08.071.

21. Frattini, A.; Pellegri, N.; Nicastro, D.; Sanctis, O.d. Effect of amine groups in the synthesis of Ag nanoparticles using aminosilanes. Mater. Chem. Phys. 2005, 94, 148-152, https://doi.org/10.1016/j.matchemphys.2005.04.023.

22. Alt, V.; Bechert, T.; Steinrücke, P.; Wagener, M.; Seidel, P.; Dingeldein, E.; Domann, E.; Schnettler, R. An in vitro assessment of the antibacterial properties and cytotoxicity of nanoparticulate silver bone cement. Biomaterials 2004, 25, 4383-4391, https://doi.org/10.1016/j.biomaterials.2003.10.078.

23. Tran, Q.H.; Nguyen, V.Q.; Le, A.-T. Corrigendum: Silver nanoparticles: synthesis, properties, toxicology, applications and perspectives ( Adv. Nat. Sci: Nanosci. Nanotechnol . 4 033001). Advances in Natural Sciences: Nanoscience and Nanotechnology 2018, 9, 049501, https://doi.org/10.1088/2043-6254/aad12b.

24. Aymonier, C.; Schlotterbeck, U.; Antonietti, L.; Zacharias, P.; Thomann, R.; Tiller, J.C.; Mecking, S. Hybrids of silver nanoparticles with amphiphilic hyperbranched macromolecules exhibiting antimicrobial properties. Chem. Commun. 2002, 3018-3019, https://doi.org/10.1039/b208575e.

25. Elahi, N.; Kamali, M.; Baghersad, M.H. Recent biomedical applications of gold nanoparticles: A review. Talanta 2018, 184, 537-556, https://doi.org/10.1016/j.talanta.2018.02.088.

26. Hartono, D.; Hody; Yang, K.-L.; Lanry Yung, L.-Y. The effect of cholesterol on protein-coated gold nanoparticle binding to liquid crystal-supported models of cell membranes. Biomaterials 2010, 31, 30083015, https://doi.org/10.1016/j.biomaterials.2010.01.003.

27. Lukianova-Hleb, E.Y.; Wagner, D.S.; Brenner, M.K.; Lapotko, D.O. Cell-specific transmembrane injection of molecular cargo with gold nanoparticle-generated transient plasmonic nanobubbles. Biomaterials 2012, 33, 5441-5450, https://doi.org/10.1016/j.biomaterials.2012.03.077.

28. Wang, R.; Deng, J.; He, D.; Yang, E.; Yang, W.; Shi, D.; Jiang, Y.; Qiu, Z.; Webster, T.J.; Shen, Y. PEGylated hollow gold nanoparticles for combined X-ray radiation and photothermal therapy in vitro and enhanced CT imaging in vivo. Nanomed. Nanotechnol. Biol. Med. 2019, 16, 195-205, https://doi.org/10.1016/j.nano.2018.12.005.

29. Shende, P.; Kasture, P.; Gaud, R.S. Nanoflowers: the future trend of nanotechnology for multi-applications. Artificial Cells, Nanomedicine, and Biotechnology 2018, 46, 413422,https://doi.org/10.1080/21691401.2018.1428812.

30. Han, L.; Kim, Y.S.; Cho, S.; Park, Y. Invertebrate Water Extracts as Biocompatible Reducing Agents for the Green Synthesis of Gold and Silver Nanoparticles. Nat. Prod. Commun. 2013, 8, 11491152,https://doi.org/10.1177/1934578X1300800830.

31. Stewart, J.E.; Zwicker, B.M. Natural and induced bactericidal activities in the hemolymph of the lobster, Homarus americanus: products of hemocyte-plasma interaction. Can. J. Microbiol. 1972, 18, 1499-1509, https://doi.org/10.1139/m72-229.

32. Noga, E.J.; Arroll, T.A.; Fan, Z. Specificity and some physicochemical characteristics of the antibacterial activity from blue crabCallinectes sapidus. Fish Shellfish Immunol. 1996, 6, 403-412, https://doi.org/10.1006/fsim.1996.0039.

33. Veeruraj, A.; Ravichandran, S.; Rameshkumar, G. Antibacterial activity of crab haemolymph on clinical pathogens. Trends in Applied Sciences Research 2008, 3, 174-181, https://doi.org/10.3923/tasr.2008.174.181.

34. Anbuchezhian, R.; Samuthirapandian, R.; Rameshkumar, G.; Ajith Kumar, T.T. Influence of Crab Haemolymph on Clinical Pathogens. Adv. Biol. Res. 2009, 3.

35. Zhang, D.; Ma, X.-1.; Gu, Y.; Huang, H.; Zhang, G.-w. Green Synthesis of Metallic Nanoparticles and Their Potential Applications to Treat Cancer. Frontiers in Chemistry 2020, 8, 799, https://doi.org/10.3389/fchem.2020.00799.

36. Lekshmi, P.; A, B.; S, J.; J, R.; Bharath, S. Synthesis of silver nanoparticles using Haemolymph of marine crabs (Carcinus maenas and Ocypode quadrata) and its influence on clinical pathogens. J. Chem. Pharm. Res. 2015, 7, 598-606.

37. Jha, A.K.; Prasad, K. Can animals too negotiate nano transformations? Advances in nano research 2013, 1 , 35,https://doi.org/10.12989/anr.2013.1.1.035. 
38. Yogalakshmi, K.N.; Das, A.; Rani, G.; Jaswal, V.; Randhawa, J.S. Nano-bioremediation: a new age technology for the treatment of dyes in textile effluents. In Bioremediation of Industrial Waste for Environmental Safety, Springer: 2020; 313-347.

39. Ramírez-García, R.; Gohil, N.; Singh, V. Chapter 21 - Recent Advances, Challenges, and Opportunities in Bioremediation of Hazardous Materials. In Phytomanagement of Polluted Sites, Pandey, V.C., Bauddh, K., Eds. Elsevier: 2019; https://doi.org/10.1016/B978-0-12-813912-7.00021-1.

40. Sarker, S.D.; Nahar, L.; Kumarasamy, Y. Microtitre plate-based antibacterial assay incorporating resazurin as an indicator of cell growth, and its application in the in vitro antibacterial screening of phytochemicals. Methods 2007, 42, 321-324, https://doi.org/10.1016/j.Ymeth.2007.01.006.

41. O'Brien, J.; Wilson, I.; Orton, T.; Pognan, F. Investigation of the Alamar Blue (resazurin) fluorescent dye for the assessment of mammalian cell cytotoxicity. Eur. J. Biochem. 2000, 267, 5421-5426, https://doi.org/10.1046/j.1432-1327.2000.01606.x.

42. Ansar Ahmed, S.; Gogal, R.M.; Walsh, J.E. A new rapid and simple non-radioactive assay to monitor and determine the proliferation of lymphocytes: an alternative to $[3 \mathrm{H}]$ thymidine incorporation assay. J. Immunol. Methods 1994, 170, 211-224,https://doi.org/10.1016/0022-1759(94)90396-4.

43. Page, B.; Page, M.; Noel, C. A new fluorometric assay for cytotoxicity measurements in-vitro. Int. J. Oncol. 1993, 3, 473-476,https://doi.org/10.3892/ijo.3.3.473.

44. McNicholl, B.P.; McGrath, J.W.; Quinn, J.P. Development and application of a resazurin-based biomass activity test for activated sludge plant management. Water Res. 2007, 41, 127133,https://doi.org/10.1016/j.watres.2006.10.002.

45. Gulnaz, A.R.; Savitha, G. Evaluation of antimicrobial activity of leaf and stem extracts of Sidda medicinal plant Sida cordata. International Journal of Medicine and Pharmaceutical Sciences 2013, 3, 39-50.

46. Bhutkar, M.; Bhise, S.B. In vitro assay of alpha amylase inhibitory activity of some indigenous plants. International Journal of Chemical Sciences $\quad \mathbf{2 0 1 2}, \quad 10, \quad 457-462$, https://doi.org/10.31031/MAPP.2018.01.000518.

47. Fuller, M.A.; Köper, I. Biomedical applications of polyelectrolyte coated spherical gold nanoparticles. Nano Convergence 2019, 6, 11, https://doi.org/10.1186/s40580-019-0183-4.

48. Chand, K.; Cao, D.; Eldin Fouad, D.; Hussain Shah, A.; Qadeer Dayo, A.; Zhu, K.; Nazim Lakhan, M.; Mehdi, G.; Dong, S. Green synthesis, characterization and photocatalytic application of silver nanoparticles synthesized by various plant extracts. Arabian Journal of Chemistry 2020, 13, 82488261,https://doi.org/10.1016/j.arabjc.2020.01.009.

49. Inbakandan, D.; Venkatesan, R.; Ajmal Khan, S. Biosynthesis of gold nanoparticles utilizing marine sponge Acanthella elongata (Dendy, 1905). Colloids Surf. B. Biointerfaces 2010, 81, 634-639, https://doi.org/10.1016/j.colsurfb.2010.08.016.

50. Stepanov, A.L.; Krenn, J.R.; Ditlbacher, H.; Hohenau, A.; Drezet, A.; Steinberger, B.; Leitner, A.; Aussenegg, F.R. Quantitative analysis of surface plasmon interaction with silver nanoparticles. Opt. Lett. 2005, 30, 1524-1526, https://doi.org/10.1364/ol.30.001524.

51. Basavegowda, N.; Kumar, G.D.; Tyliszczak, B.; Wzorek, Z.; Sobczak-Kupiec, A. One-step synthesis of highly-biocompatible spherical gold nanoparticles using Artocarpus heterophyllus Lam.(jackfruit) fruit extract and its effect on pathogens. Ann. Agric. Environ. Med. 2015, 22, https://doi.org/10.5604/12321966.1141374.

52. Shankar, S.S.; Rai, A.; Ahmad, A.; Sastry, M. Rapid synthesis of Au, Ag, and bimetallic Au core-Ag shell nanoparticles using Neem (Azadirachta indica) leaf broth. J. Colloid Interface Sci. 2004, 275, 496-502, https://doi.org/10.1016/j.jcis.2004.03.003.

53. Sadiq, M.B.; Hanpithakpong, W.; Tarning, J.; Anal, A.K. Screening of phytochemicals and in vitro evaluation of antibacterial and antioxidant activities of leaves, pods and bark extracts of Acacia nilotica (L.) Del. Industrial Crops and Products 2015, 77, 873-882,https://doi.org/10.1016/j.indcrop.ELsievier2015.09.067.

54. D'Angelo, J.A.; Zodrow, E.L. Chemometric study of functional groups in different layers of Trigonocarpus grandis ovules (Pennsylvanian seed fern, Canada). Org. Geochem. 2011, 42, 10391054,https://doi.org/10.1016/j.orggeochem.2011.06.022.

55. Lee, Y.J.; Ahn, E.-Y.; Park, Y. Shape-dependent cytotoxicity and cellular uptake of gold nanoparticles synthesized using green tea extract. Nanoscale Research Letters 2019, 14, 129, https://doi.org/10.1186/s11671-019-2967-1. 
56. Gopinath, V.; MubarakAli, D.; Priyadarshini, S.; Priyadharsshini, N.M.; Thajuddin, N.; Velusamy, P. Biosynthesis of silver nanoparticles from Tribulus terrestris and its antimicrobial activity: A novel biological approach. Colloids Surf. B. Biointerfaces 2012, 96, 69-74, https://doi.org/10.1016/j.colsurfb.2012.03.023.

57. Vo, T.-T.; Nguyen, T.T.-N.; Huynh, T.T.-T.; Vo, T.T.-T.; Nguyen, T.T.-N.; Nguyen, D.-T.; Dang, V.-S.; Dang, C.-H.; Nguyen, T.-D. Biosynthesis of Silver and Gold Nanoparticles Using Aqueous Extract from Crinum latifolium Leaf and Their Applications Forward Antibacterial Effect and Wastewater Treatment. Journal of Nanomaterials 2019, 2019, 8385935,https://doi.org/10.1155/2019/8385935.

58. Giannini, C.; Ladisa, M.; Altamura, D.; Siliqi, D.; Sibillano, T.; De Caro, L. X-ray Diffraction: A Powerful Technique for the Multiple-Length-Scale Structural Analysis of Nanomaterials. Crystals 2016, 6,https://doi.org/10.3390/cryst6080087.

59. Garibo, D.; Borbón-Nuñez, H.A.; de León, J.N.D.; García Mendoza, E.; Estrada, I.; Toledano-Magaña, Y.; Tiznado, H.; Ovalle-Marroquin, M.; Soto-Ramos, A.G.; Blanco, A.; Rodríguez, J.A.; Romo, O.A.; ChávezAlmazán, L.A.; Susarrey-Arce, A. Green synthesis of silver nanoparticles using Lysiloma acapulcensis exhibit high-antimicrobial activity. Sci. Rep. 2020, 10, 12805, https://doi.org/10.1038/s41598-020-69606-7.

60. Singh, J.; Dutta, T.; Kim, K.-H.; Rawat, M.; Samddar, P.; Kumar, P. 'Green' synthesis of metals and their oxide nanoparticles: applications for environmental remediation. Journal of Nanobiotechnology 2018, 16, 84, https://doi.org/10.1186/s12951-018-0408-4.

61. Badeggi, U.M.; Badmus, J.A.; Botha, S.S.; Ismail, E.; Marnewick, J.L.; Africa, C.W.J.; Hussein, A.A. Biosynthesis, Characterization, and Biological Activities of Procyanidin Capped Silver Nanoparticles. Journal of Functional Biomaterials 2020, 11,https://doi.org/10.3390/jfb11030066.

62. Singh, R.; Sahu, S.K.; Thangaraj, M. Biosynthesis of Silver Nanoparticles by Marine Invertebrate (Polychaete) and Assessment of Its Efficacy against Human Pathogens. Journal of Nanoparticles 2014, 2014, 718240, https://doi.org/10.1155/2014/718240.

63. Valsalam, S.; Agastian, P.; Arasu, M.V.; Al-Dhabi, N.A.; Ghilan, A.-K.M.; Kaviyarasu, K.; Ravindran, B.; Chang, S.W.; Arokiyaraj, S. Rapid biosynthesis and characterization of silver nanoparticles from the leaf extract of Tropaeolum majus L. and its enhanced in-vitro antibacterial, antifungal, antioxidant and anticancer

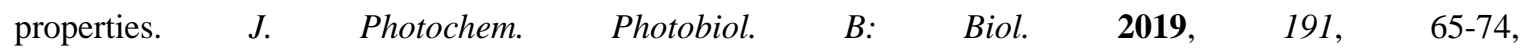
https://doi.org/10.1016/j.jphotobiol.2018.12.010.

64. Manohar, V.; Talpur, N.A.; Echard, B.W.; Lieberman, S.; Preuss, H.G. Effects of a water-soluble extract of maitake mushroom on circulating glucose/insulin concentrations in KK mice. Diabetes, Obesity and Metabolism 2002, 4, 43-48, https://doi.org/10.1046/j.1463-1326.2002.00180.x.

65. Kwon, Y.-I.; Apostolidis, E.; Shetty, K. EVALUATION OF PEPPER (CAPSICUM ANNUUM) FOR MANAGEMENT OF DIABETES AND HYPERTENSION. J. Food Biochem. 2007, 31, 370-385, https://doi.org/10.1111/j.1745-4514.2007.00120.x

66. Matsui, T.; Ogunwande, I.A.; Abesundara, K.J.M.; Matsumoto, K. Anti-hyperglycemic Potential of Natural Products. Mini-Rev. Med. Chem. 2006, 6, 349-356, https://doi.org/10.2174/138955706776073484.

67. Matsuda, H.; Morikawa, T.; Yoshikawa, M. Antidiabetogenic constituents from several natural medicines. Pure Appl. Chem. 2002, 74, 1301-1308, https://doi.org/10.1351/pac200274071301.

68. Saratale, R.G.; Shin, H.S.; Kumar, G.; Benelli, G.; Kim, D.-S.; Saratale, G.D. Exploiting antidiabetic activity of silver nanoparticles synthesized using Punica granatum leaves and anticancer potential against human liver cancer cells (HepG2). Artificial Cells, Nanomedicine, and Biotechnology 2018, 46, 211-222, https://doi.org/10.1080/21691401.2017.1337031.

69. Debnath, G.; Das, P.; Saha, A.K. Characterization, Antimicrobial and $\alpha$-Amylase Inhibitory Activity of Silver Nanoparticles Synthesized by using Mushroom Extract of Lentinus tuber-regium. Proceedings of the National Academy of Sciences, India Section B: Biological Sciences 2020, 90, 37-45, https://doi.org/10.1007/s40011-019-01076-y. 